\title{
Cannabis sativa and rural livelihoods in South Africa: politics of cultivation, trade and value in Pondoland
}

\author{
Thembela Kepe ${ }^{1}$
}

Current debate on Cannabis sativa in South Africa has centred on its positive and negative effects on health, as well as its decriminalisation. The contribution of cannabis (dagga) to the livelihoods of people who inhabit some of the poorest parts of the country has thus far been largely ignored. Using a case study of a village in Pondoland, this article argues that while cannabis makes a significant contribution to the livelihoods of many households, the values derived by cannabis farmers vary widely, as determined by social difference, the illegal nature of cannabis production and trade, and the cannabis commodity chain. Furthermore, lobbies to legalise cannabis will not necessarily yield positive results for poor rural cannabis growers, as this could result in lower prices due to the possibility of increased supply, as well as the fact that illegality is what currently keeps the prices fairly high.

\section{INTRODUCTION}

The uniqueness of the Cannabis sativa plant is widely acknowledged. In addition to being known by as many names as perhaps there are languages or subcultures that use it (see Du Toit, 1996), it is one plant whose use by human beings has been the subject of almost a century-long debate by users, practitioners and scholars alike. The publication of the composite work Cannabis and culture (Rubin, 1975) is perhaps a good illustration of how professionals from diverse disciplines (e.g. botany, anthropology, psychology, pharmacy, law, etc.) are fascinated by this plant. Almost 30 years later, the debate about the benefits or dangers of $C$. sativa to human beings is still as intense as it was when the book was first published.

While the literature on cannabis has extensively covered the multiple uses of the plant - for medicinal purposes (Grinspoon, 1994; Bello, 1996), for hemp fibre (Wynn, 1998), etc. - it has been its use as a mind-altering drug that has captured much of the public attention. However, as a banned plant in many countries, and as a result of extensive lobbying for its unbanning for spiritual, medicinal and fibre purposes, some of the key contributions of this plant have been largely ignored in the literature. In South Africa, the coverage of cannabis in literature has mainly focused on the psychoactive properties of the plant (e.g. Zabow, 1995) and questions about its legalisation (Smith, 1995; Khan, 1996; Thole, 2001). Other than police reports about arrests of offenders found in possession of cannabis in rural areas, the destruction of cannabis plantations (see Maqhina, 2001) and brief reports by some journalists on the geographical origins of the cannabis sold in cities (e.g. Ngani, 1997), rural areas have received little coverage. In particular, few writers have attempted to understand the

\footnotetext{
${ }^{1}$ Research Fellow, Programme for Land and Agrarian Studies, University of the Western Cape, Bellville, South Africa.
} 
socio-economic implications of growing cannabis in rural areas of South Africa. Instead, romanticisation of the plant by some writers has led to the popular label of 'green gold', implying that cannabis has the potential to make those who trade in it become wealthy and that it can be a panacea for poverty (Ngani, 1997; Nevill \& Stephen, 1998). In such writing, social differences are usually ignored.

The purpose of this article is to examine, through a village case study, social dynamics relating to the cultivation of cannabis by rural people, and the role of legislation and the commodity chain in determining the monetary value that can be realised by trading in cannabis. In the first of four sections that follow, a brief overview of the case study, including the methodology, is provided. This is followed by a detailed contextual analysis of the use and livelihood aspects of $C$. sativa in South Africa, at both national and local levels. The third section explores how institutional dynamics - land tenure, cannabis legislation and the commodity chain - mediate the value of cannabis to rural livelihoods. The article concludes with a section that draws lessons for research and policy with regard to cannabis as a key resource in the livelihoods of rural South Africans.

\section{THE STUDY AREA AND RESEARCH DESIGN}

The article is based on a case study of 'Mlanjeni Village' (not its real name), situated in the Pondoland region of the Wild Coast, in the Eastern Cape province. The Eastern Cape is the poorest province in South Africa, with poor infrastructure and high levels of unemployment (DEAT, 2001). The area is inhabited by the Xhosa-speaking people (amaMpondo), who generate their livelihoods through a mixture of arable and livestock farming, the collection of a range of natural resources, and a range of off-farm sources, including remittances and pensions. While the area has rich biodiversity, as well as a climate that allows rainfed cropping, poor soil conditions limit extensive crop production, especially of the locally favoured maize.

A variety of methods were used to collect the data analysed and presented in this article. In addition to long-term observation of livelihood strategies over a five-year period (1996-2000), which included a nine-month, full-time residence in the village, views of key informants from different households were obtained during numerous visits. However, it is important to note that the information presented in this article did not come easily. The researcher had to be both patient and opportunistic in learning about cannabis-growing activities in Mlanjeni Village and its surroundings. First, due to the criminalisation of cannabis in South Africa, few villagers were prepared to talk freely about their own involvement in growing the plant. Instead, villagers would rather talk about what other people were doing, even if these were their close relatives, while they pretended that they themselves were not involved. The researcher was gradually able to gain the trust of some growers who had initially pretended that they were not involved in planting cannabis. Secondly, other than direct interviews, the researcher gained information during traditional beer-drinking parties, where men talked uninhibitedly about cannabis growing, sale and consumption in the village and beyond. Lastly, newspapers and other secondary material were useful in learning about the legal aspects of growing, sale and use of cannabis in South Africa.

\section{CANNABIS IN SOUTH AFRICA: NATIONAL AND LOCAL CONTEXT}

The use of $C$. sativa by the people of South Africa goes back many centuries. Du Toit 
(1974, 1996) argues that cannabis has been used in Africa for at least six centuries, after Arab traders introduced it from other parts of the world. In southern Africa, Zulu, Sotho and Swazi warriors smoked cannabis before battle in order to gain energy and self-confidence. For praise singers and diviners, cannabis was thought to clear their minds, while it was seen to increase work efficiency and cure certain diseases (e.g. malaria) for people in general (Du Toit, 1980).

For most of the 20th century, the local term for $C$. sativa that is commonly used in non-indigenous social, medical and legal writing has been 'dagga'. Xhosa-speaking people in the Eastern Cape, on the other hand, refer to cannabis as umya or intsangu. According to Schutze (1998), until 1905 white Cape farmers ran a profitable trade by growing cannabis. Around this time some farmers wanted it banned because some of their workers were allegedly abusing it. By the year 2000, almost a century since this initial ban, cannabis sales in South Africa are estimated to be worth R5 billion per year (Gerardy, 2000). While $C$. sativa is a key component of several Western and traditional medicines (Van Wyk et al., 1997), most of what is grown in South Africa is currently used as a recreational drug. KwaZulu/Natal and the Eastern Cape are the major producers of the cannabis found in the cities (Smith, 1995; Khan, 1996; Gerardy, 2000; Thole, 2001). South African consumers buy dagga in a variety of forms, the most common being plastic bank bags ('bankies' - about $10 \mathrm{~g}$ each), tightly rolled cigars ('stoppe'), matchboxes and parcels (shopping plastic bags). The price in the street ranges between R2 per matchbox to a few hundred rand per parcel, depending on size and scarcity.

The former Transkei in the Eastern Cape province has long been known as a major cannabis-producing area, leading some writers and politicians to argue that, if legalised, it could boost the region's ailing economy (Ngani, 1997). While cannabis is grown in most parts of the Wild Coast stretch of the former Transkei, Eastern Pondoland has been producing the most cannabis for many decades (Beinart, 1982; Ngani, 1997). Eastern Pondoland's broken countryside-gorges, enclaves and ravines-makes it difficult for the police to gain access to the cannabis plantations. Hence, in a recent pilot project to grow hemp for industrial purposes, Eastern Pondoland was excluded on the grounds that it would be difficult to distinguish between the cannabis grown for drug trafficking and that which is grown for producing fibre and oil (Wynn, 1998).

Whether banned or not, it appears that Pondoland's cannabis will continue to attract both public attention and consumers. Recently, Denis Beckett, a controversial host of a television travel show, took a few puffs from a dagga joint while in the Pondoland, on national television. This act, which many considered outrageous, received further publicity in the national media. Moreover, as part of the ecotourism endeavour in the Wild Coast, an alternative trip marketed as 'The Marijuana Trail', which began in November 2000, hopes to attract young European backpackers (Dickson, 2000). While the organisers of the trail do not promise to sell cannabis themselves, one of them was quoted as saying 'the marijuana is there ... if that's your thing, and you buy it from the locals, we can't stop you' (Dickson, 2000). In reality, many tourists and merchants from the cities are some of the most valuable customers of the local cannabis growers in the Wild Coast. However, even in this cannabis grower's 'paradise' (Schutze, 1998), the extent to which it is grown and traded differs from one village to another, as well as from one household to another. In other words, the value derived by villagers from the use and sale of cannabis is highly differentiated, being mediated by various lines 
of social difference, ecological factors and social institutions. The next section discusses some of these dynamics for a village in Pondoland.

\section{CASE STUDY}

\subsection{Categories of growers in Mlanjeni Village}

For many decades the Lusikisiki area, within which Mlanjeni falls, has been known to produce the best dagga in the country. There are at least three categories of cannabis growers in Mlanjeni. All the growers are male and reside in the village for most of the year. First, at the lower end, there are ababhemi bentsangu (dagga smokers). These are men who plant just enough cannabis to satisfy their own needs. The ecological sites these men choose largely depend on the person's age and status within the household. For example, if the dagga smoker is the de facto head of the household or a senior member, patches of between $2-10 \mathrm{~m}^{2}$ could be planted in the homestead area, mostly amongst crops. On the other hand, if the smoker is a boy whose parents or relatives do not approve of his smoking cannabis, the patch is often planted in the forest or near streams, far away from the settlement area. People in this first category usually do not sell their crop. They might, however, share it with other smokers, in return for a similar favour when they do not have any in their gardens.

The second category of cannabis growers is that of people who smoke, but also sell surplus to other villagers. If these people are not smokers themselves, they grow the cannabis to feed to their horses to make the animals 'go faster'. Since the early 1990s, during the time of accelerated political change in the country, people in this category have been growing their crop in their homestead gardens instead of the forests or gorges. However, growing cannabis nearer to the homesteads has created new challenges for the growers, as police who are in the village to attend to other matters often surprise them. Consequently, people who are able to maintain their cannabis-growing activities are those who are sober and dedicated.

The third category of cannabis growers is that of abadakisi bentsangu (people who trade with cannabis). These are people who are known within and outside the village as full-time cannabis traders. There are 13 such traders who live in Mlanjeni, most of whom are married males and have relatively large families. What is interesting about these traders is that they do not fit the popular profile of cannabis traders from Pondoland, as reported in the media (e.g. Ngani, 1997). It is often reported in newspapers that cannabis traders from Pondoland are rich people who own expensive homes, cars and many livestock. Contrary to this, most of the Mlanjeni traders are not known as rich people, because none of them have expensive assets. It is common knowledge that while city dealers make profits of about R1 000 per kilogram of cannabis, the village farmers' share is about R40 per kilogram (Smith, 1995) or even less, at R16 per kilogram (Schutze, 1998). This discrepancy is widely seen by village traders as a feature they cannot wish away, especially if laws regarding possession and trade with cannabis remain the same.

With the exception of one trader, who has city clients coming to the village to buy in large quantities, Mlanjeni cannabis traders keep their operations fairly moderate, preferring to sell in small quantities within the village or sending manageable amounts by bus to Durban, in order to minimise the chances of being targeted by law enforcement. Other than owning some livestock, the traders display very few signs of wealth. Moreover, the small scale of operations, combined with the fact that Mlanjeni 
traders are mostly elderly men with large families, may partly be responsible for this area attracting very little attention from law enforcers. Large families and limited formal education of rural people are generally associated with poverty, not with a prosperous dagga operation. The minimal harassment by the police may also be due to the ecological or physical location of the cannabis operation. The next subsection, therefore, focuses on how the ecological aspects of a local operation contribute to determining the value of cannabis for different households.

\subsection{Ecological dynamics}

Almost all the cannabis found in the area is planted, as opposed to occurring naturally. Cannabis is cultivated throughout the year, but the ideal growing season is between October and March. Consumers in the cities argue that cannabis grown during this period is of very good quality (Leggett \& Burton, 1999). It normally takes about four to six months for the crop to be ready for harvest. As the plant can grow up to several metres in height, one of the main chores during the growing season, in addition to weeding, is pruning the plants at the top. Local informants argue that this helps to maintain a shorter height for the plant, something that makes it less visible to unwelcome observers.

The site where dagga is grown in the village is largely determined by both social differences amongst growers and the place of cannabis in a household's livelihood complex. Adult men who plant cannabis mainly for own consumption, while only selling small amounts of surplus, often plant it in the homestead garden. Established growers who invest effort in growing cannabis as a key aspect of their livelihood have their plantations deep in the forests. Just as underage dagga smokers in the village, established traders see the forest as the best place to hide the gardens away from the prying eyes of disapproving relatives or law enforcement officers.

While cannabis grows successfully in varied and even harsh environmental conditions (Ryan, 1998), the forests appear to offer the growers additional benefits. The soil there tends to be fertile and is rarely dry for long periods. Most of the forests where cannabis is grown are situated on or near the river banks, where alluvial soils dominate. Such soils are known to be relatively rich in nutrients (Kepe, 1997). However, the rich forest soils do not by themselves guarantee high profits. An array of social institutions mediates values derived from growing cannabis, as discussed in the next section.

\subsection{Institutional dynamics of the cannabis trade}

Two clusters of institutions or practices are crucial for those trading in $C$. sativa. These have to do with land tenure and the legal frameworks dealing with the use of and trading with cannabis. Furthermore, the cannabis commodity chain is also crucial in determining the realised value.

\subsubsection{Land tenure}

The two types of sites where cannabis is planted (the homestead garden and the forest areas) fall under two different tenure regimes. The homestead garden is a de facto private property, while the forest area is common property. The planting of cannabis in private gardens, therefore, appears a straightforward matter. As with many other crops (maize, grass, etc.) that are planted in homestead gardens, members of the 
household can, in principle, make their own decision with regard to planting cannabis. However, while de facto household heads normally do not have to seek approval from other members of the household to plant maize or other common domestic crops in their gardens, this is not always the case with cannabis.

This point is best illustrated by the case of the late CP. CP, the oldest child of CM, became a de facto head of the household when his father died in 1997. He made almost all decisions about cultivation in their homestead garden, without any challenge from his infirm mother or other relatives. Things changed in 1998 when CP planted cannabis in the garden. His mother clearly did not approve of this action. She told people she was worried that $\mathrm{CP}$ was going to turn their household into a drug dealership. For over two years, CP argued that the cannabis in their garden was too little to be considered as being used for trafficking. This tension between mother and son only ended late in 1999, when CP became ill and was hospitalised for a few weeks. His mother seized the opportunity presented by his absence and ordered children to uproot all the cannabis from the garden. When CP came out of the hospital he was too weak to revive his cannabis garden. He eventually died in 2000.

While CP and CM's case may at first appear as an internal conflict between members of a single household, it illustrates that de facto ownership of a piece of land does not always translate into having decision-making authority over it. Observations made in Mlanjeni show that when cannabis is planted in homestead gardens, it is usually with the tacit blessing of household members, the neighbours and village leaders. Were these people not approving, two things could happen. First, kin members could remove the plants from the garden by force. Secondly, the neighbours and village leaders could apply the same principle that applies to other 'serious' offenders, namely expulsion from the village. Between 1996 and 2000, for example, eight people from Mlanjeni had to abandon their sites, including all their huts and gardens, due to being expelled for transgressions such as witchcraft, stock theft, using fire as a weapon against a neighbour and attacking other people's livestock with deadly weapons. It appears that private property ownership is not respected when other villagers agree that one has broken a law. Therefore, the successful growing of cannabis on private property is indeed at the mercy of other villagers and how they perceive the operation.

Unlike the homestead gardens that belong to individuals and households, the forests where established cannabis traders have their plantations are understood to be common property. According to local practice, people can only claim de facto private ownership of a space if they have been allocated one by village or political structures. Other than people protecting patches of thatch grass or women planting sedges in streams, people who need more space (e.g. for a stock-post), have to seek permission from the traditional authorities or local political structures. However, it appears that for many decades cannabis traders never formally sought such permission. According to informants, planting cannabis in the forests was much easier 70 or so years ago because most people still had homesteads in or near the forests in the gorges. The forests were therefore simply an extension of the homestead area for many people. These days, however, almost everybody in the area lives in the 'topland', $2-5 \mathrm{~km}$ from the gorges, making a forest cannabis plantation a clearly separate space from the homestead.

It also appears that no traditional or political structure wants to be held responsible for allocating land for an illegal activity such as growing cannabis. In other words, a person can establish a cannabis plot in the forest without fear of being prosecuted by the village leadership for not seeking permission first. However, the establishment of 
that garden does not necessarily make it acceptable in terms of local practice, especially if we agree with Vandergeest's (1997) assertion that its better to think about property as 'practices' rather than as rules. The village leadership distances itself from anything that happens to the cannabis garden or to the owner as a result of owning it. For example, if someone stole cannabis from another person's homestead or forest garden, the village leadership does not become involved. Under normal circumstances, the village leaders would mediate cases of theft from a person's garden. This puts cannabis growers in a difficult position, as one prominent trader commented:

Many youth are now stealing from the cannabis plantations because they know we can't report them to the chief. We are owners without real rights. If you have a cannabis garden in the forest, people have to fear or respect you, not the village law, because there is no village law about an intsangu garden. We just do it. If they respect or fear you, everything goes well. They can't even bypass the chief or other local leaders and go to the police.

To sum up, the illegal nature of the cannabis trade prevents the growers from having protected rights. The security and protection of a cannabis grower's forest garden largely depends on what people in the village think of him or her. Without the respect of or protection from other villagers the realised value of a forest garden cannot be maximised. Had local people accepted the garden, things would perhaps have been different - even more so, had cannabis been a legal crop. This next section deals with legal frameworks relating to the use of and trading with cannabis, and how these frameworks can determine the value of the crop for a household.

\subsubsection{Cannabis legislation and enforcement}

During most of the 20th century, legislation pertaining to the use of cannabis in South Africa has perhaps been the biggest factor determining how much value individuals derive from trading with it. The cultivation, sale and consumption of $C$. sativa in South Africa were first outlawed, formally, under the Medical, Dental and Pharmacy Act (No. 13 of 1928). In 1971, the anti-cannabis legislation was stiffened with the passing of the Abuse of Dependence-producing Substances and Rehabilitation Centres Act (No. 41 of 1971, Schedule I). Following at least five amendments to the 1971 Act, the Drugs and Drug Trafficking Act (No. 140 of 1992), which is currently in effect, was passed. According to Section 17 of this Act, use or possession of cannabis is punishable with a fine and/or a prison sentence of not more than 15 years. Most relevant to the people who cultivate cannabis in Mlanjeni is Section 21.1(i) of this Act, which states that a person found in possession of more than 115 gram of cannabis is considered a dealer and could be fined and/or imprisoned for a maximum of 25 years. In addition to this legislation, the Weeds Act (No. 42 of 1937) made provision for the eradication of certain weeds, including cannabis. Owners or occupiers of land could be prosecuted for not removing or notifying authorities about the presence of the plant (wild or cultivated) on their land (Union of South Africa, 1952).

The South African Narcotics Bureau (SANAB) is the national law enforcement agency dealing with cannabis crimes, and has offices throughout the country. During the 1990s, the majority of cannabis prosecutions were for possession and dealing offences (Smith, 1995; Nevill \& Stephen, 1998), with only a few mentioned cases being tried for cultivation. However, the low number of arrests for the cultivation of cannabis does not mean that SANAB is not fighting such cultivation. Rather, law enforcement has for many years taken a different approach to cannabis crops in rural areas. This involved 
destroying cannabis growing in rural plantations through burning or spraying with chemicals (Cooper, 1994; Smith, 1995; Daily Dispatch, 1999; Maqhina, 2001). One of the main reasons for taking this approach was the limited success achieved by the police in convicting alleged cannabis farmers. Police complain that villagers desert their fields and homes and run to the mountains whenever they see police vehicles approaching from a distance (Maqhina, 2001). The police are therefore forced to deal with the matter by burning or spraying the plantations. Unless villagers are willing to act as informers, SANAB has limited strategies for convicting cannabis growers in rural areas. The paying of informers by the police, in order to gain convictions in cannabis-related crimes in rural areas, has been a practice in South Africa for most of the 20th century. However, it appears that this strategy has not been a success (see Union of South Africa, 1952; Gerardy, 2000).

Based on the above discussion, it would appear that other than by facilitating the destruction of cannabis plantations through spraying and burning them, legal frameworks have, thus far, had less impact on the actual cultivation of cannabis. However, there are at least two ways in which the legal frameworks affect the value of the crop for individuals and households. First, by restricting the storage, transportation and sale of the crop, laws discourage careless, unskilled or fearful people from entering the trade or from maximising their benefits. Hence some of Mlanjeni's cannabis traders are prepared to receive less cash if somebody else is willing to take the risk of storing and then transporting the cannabis to city markets. As mentioned earlier, convictions for possession - including being caught while transporting cannabis - account for a considerable number of those convicted under the Drugs and Drug Trafficking Act (No. 140 of 1992). Villagers who do not have networks for transporting cannabis, or who are not willing to take the risk of transporting it themselves, are also forced to accept reduced values by selling within the village.

In addition, because cannabis is an illegal crop, there is a socially constructed scarcity that determines its price or value. In other words, both the traders and the consumers understand that the price of cannabis, over and above conventional production costs, also covers the risk of prosecution. This is why some people have not been supportive of the legalisation of dagga, arguing that it will remove the 'scarcity' mystery surrounding it, and the prices could go down and hurt the growers (Smith, 1995). To sum up, it would appear that the harsher the laws and enforcement against the growing, sale and use of cannabis, the higher the potential economic values from trading with this crop. However, as we have seen, the same legal frameworks could mean lower profits to the traders, depending on a number of factors.

In addition to physical strategies such as concealment during cultivation, storage and transportation of cannabis that villagers from Pondoland have developed, new ways of responding to the restrictive legal frameworks affecting their livelihoods from $C$. sativa have equally been on the increase over the last few years. The bribing of corrupt police officers is common in many cannabis-producing areas of Pondoland. Even the traditional authorities that have, for most of the 20th century, been assisting police in apprehending cannabis traders in the former Bantustans (Union of South Africa, 1952), have faced new challenges. A combination of blackmail and poverty appears to have contributed to the demise of the role played by traditional authorities in the implementation of anti-cannabis legislation over the last few years. First, following the political awakening of the 1990s, cannabis users and traders have become less fearful of 
traditional authorities. Secondly, informants revealed that some chiefs also accept bribes given by cannabis traders, as a way of getting out of poverty.

Apart from what the cannabis traders can do themselves to counteract the negative impact of legislation on the value they may derive from their crops, the decriminalisation lobby has been their greatest ally. The support for decriminalisation of cannabis has come from politicians, health professionals, Rastafarians and academics. However, what exactly these different groups support varies widely. For example, health care professionals who may argue for legislation that allows the use of cannabis in the treatment of certain diseases, are not necessarily lobbying for the decriminalisation of cannabis for smoking purposes (Ames, 1995; Smith, 1995). Some, including politicians, argue for softer sentences against dagga users, where offenders could escape jail terms or would not even be arrested for possession of only small amounts (Harford, 1995). Support has also come from environmental activists such as the Wildlife Society, which argues that criminalisation of cannabis destroys the environment in at least two ways. First, cannabis farmers are compelled to move into sensitive environments such as indigenous forests, high mountain gulleys and steep-sided ravines, in their attempts to hide from the police (Cooper, 1994). Secondly, the use of burning and spraying with chemicals such as glycefate, as a way of destroying cannabis crops in rural areas, damages the sensitive environment (Cooper, 1994; Smith, 1995).

While supporting decriminalisation of $C$. sativa, some people have indicated their concern about the impact that this move would have on the rural cannabis farmers. For instance, Schutze (1998) argues that if cannabis were decriminalised, it would open the market to large business that would eventually outcompete the rural growers. Supporters of this argument, therefore, argue for lenient policies towards cannabis in a way that would still allow growers in rural areas to benefit through selling to city traders. As this debate continues, many small-scale cannabis farmers remain unaware that their fate is currently being decided in picket lines, courts or Parliament. They seem more concerned about how they can increase the value of their enterprises. They are, however, very aware that these values depend on complex and interlinked factors, not least amongst which is the commodity chain of cannabis.

\subsubsection{Cannabis commodity chain}

The commodity chain analysis is important for understanding who benefits, and by how much, from cannabis. As mentioned earlier, some traders from Mlanjeni rely on other people to take the cannabis to the city markets, while others double as retailers. The difference between the two types of growers is by how far each is willing to risk arrest. As one goes further up in the commodity chain, the more benefit there is likely to be. However, these higher benefits come with greater risks. Growers who transport their cannabis to the city have to be prepared to part with some of their potential revenue to pay for transport and the occasional bribes to the drivers or police friends on the way. Those people who make R20 000 profits in Durban (Leggett \& Burton, 1999) get the most benefits, but by getting other people to sell for them on the street corners, it is doubtful whether they also take the most risk. However, cannabis growers from the village seem to be content with getting the smallest share of the revenue, as they feel they have less amandla, or strength, to survive the fines and jail terms.

To conclude, this section has shown that institutional dynamics - ranging from tenure rights to cannabis legislation - play the biggest role in determining how much value 
can be derived by villagers from growing and selling cannabis. First, the ability of a cannabis trader to secure suitable land for cultivation largely depends on the support of fellow villagers or family. If this support exists, the land tenure of a trader becomes somewhat secure. This security of tenure goes along with indirect protection from the law, as villagers often refuse to act as informers against their fellow members. Secondly, legislation against cannabis does not only affect traders by restricting cultivation. It also restricts the market flow of the product to the primary consumers, who are mainly in the cities. Traders' ability to find a suitable marketing channel for their crop enhances the value they can derive from it. In this sense, cannabis is not very different from other agricultural commodities. As Cocklin et al. (1999) argue, the production of cannabis is governed by the same basic economic principles as other legal crops. The only distinguishing fact is the absence of regulation through such things as taxation, tariffs and industry policy.

\section{DISCUSSION AND CONCLUSION}

This article has used a village case study to show that cannabis is important in the rural economy of poor areas, but that values derived from it vary widely from one household to another. The case study has shown that distance from tarred roads, social differences, land tenure and legal frameworks are key factors determining the monetary values a household derives. First, cannabis farmers who live far from the tarred roads, as is the case with the villagers of Mlanjeni, have smaller operations due the scarcity of city customers, who prefer accessible roads. Secondly, while land is available to farmers who cultivate cannabis, their tenure can be dynamic due to the fact that they are not protected by formal or informal laws governing land allocation in villages. Farmers are reluctant to risk investing in large operations on land that legally does not belong to them. Thirdly, the laws against the possession and sale of cannabis seem to encourage cannabis farmers to have smaller operations. They appear unwilling to take maximum risk while transporting to and selling the product in the cities. Hence many are satisfied with selling only locally, or accepting lower revenues by entering into partnerships with people who are willing to take the risk.

The overall conclusion of this case study is that cannabis is key to the rural livelihoods of some villagers. However, contrary to popular belief that most cannabis farmers prosper from selling dagga, there are instances where cannabis makes only a steady contribution to the livelihood of a household. In other words, not all cannabis growers are wealthy people. The illegal nature of cannabis possession and trade appears to be a key determinant in how much value households can derive from their dealing in this crop. Ironically, however, it is the illegal nature of the trade that keeps the prices high.

\section{REFERENCES}

AMES, FR, 1995. Cannabis sativa: a plea for decriminalisation. South African Medical Journal, 85(12): 1268-9.

BEINART, W, 1982. The political economy of Pondoland, 1860 to 1930. Johannesburg: Ravan.

BELLO, J, 1996. The benefits of marijuana: physical, psychological and spiritual. Cottonwood: Swetlight.

COCKLIN, C, WALKER, L \& BLUNDEN, G, 1999. Cannabis highs and lows: sustaining and dislocating rural communities in Northland, New Zealand. Journal of Rural Studies, 15(3): 241-55. 
COOPER, K, 1994. Wildlife Society policy on growing dagga in South Africa. The Naturalist, 38(2): 28.

DAILY DISPATCH, 1999. E Cape last stop for anti-dagga spray, 17 September.

DEPARTMENT OF ENVIRONMENTAL AFFAIRS AND TOURISM (DEAT), 2001.

Sustaining development in South Africa: an analytical review of progress towards sustainable development. Pretoria: DEAT.

DICKSON, P, 2000. Transkei tourists take the high road. Mail \& Guardian, 27 October -2 November.

DU TOIT, BM, 1974. Cannabis sativa in sub-Saharan Africa. South African Journal of Science, 70(9): 266-70.

DU TOIT, BM, 1980. Cannabis in Africa. Rotterdam: AA Balkema.

DU TOIT, BM, 1996. Pot by any other name is still ...: a study of the diffusion of cannabis. South African Journal of Ethnology, 19(4): 127-35.

GERARDY, J, 2000. SA dagga yield at least R5bn a year. Daily Dispatch, 25 November.

GRINSPOON, L, 1994. Marihuana reconsidered, 2nd edn. Oakland: Quick American Archives.

HARFORD, D, 1995. SA needs 'responsible' approach to dagga debate. Mayibuye, 6(4): 7.

KEPE, T, 1997. Environmental entitlements in Mkambati: livelihoods, social institutions and environmental change on the Wild Coast of the Eastern Cape. Research Report No. 1, Programme for Land and Agrarian Studies, School of Government. Bellville: University of the Western Cape.

KHAN, F, 1996. Should dagga be legalized? Veld \& Flora, 82(1): 20-1.

LEGGETT, T \& BURTON, K, 1999. Now selling in the point: talking to Durban's drug syndicates. Crime and Conflict, 16: 12-6.

MAQHINA, M, 2001. Dagga worth R14m burnt. Daily Dispatch, 6 April.

NEVILL, G \& STEPHEN, J, 1998. Green gold or demon weed? The Big Issue (Cape Town), 2(14): 8-10.

NGANI, P, 1997. Green gold presents moral dilemma for Transkei. Daily Dispatch, 28 March.

RUBIN, V (ED.), 1975. Cannabis and culture. The Hague: Mouton.

RYAN, T, 1998. Letting the public into the dagga debate. Mail \& Guardian, 6 March. SCHUTZE, E, 1998. The dope on dope in South Africa. Unpublished document, The Netherlands.

SMITH, A, 1995. Cannabis confusion: criminalization and decriminalization revisited. Unpublished Criminology Honours thesis. Cape Town: University of Cape Town.

THOLE, D, 2001. To smoke or not to smoke - a debate SA finds perplexing. Business Day, 15 May.

UNION OF SOUTH AFRICA, 1952. Report of the Interdepartmental Committee on the abuse of dagga. Pretoria: Government Printer.

VANDERGEEST, P, 1997. Rethinking property. Common Property Resource Digest, 41: 4-6.

VAN WYK, B, VAN OUDTSHOORN, B \& GERICKE, N, 1997. Medicinal plants of South Africa. Pretoria: Briza.

WYNN, J, 1998. South African hemp feasibility report. Rustenburg: South African BAST Crop Consortium.

ZABOW, T, 1995. Cannabis sativa - deceptive weed? South African Medical Journal, 85(12): 1269-70. 
Copyright of Development Southern Africa is the property of Carfax Publishing Company and its content may not be copied or emailed to multiple sites or posted to a listserv without the copyright holder's express written permission. However, users may print, download, or email articles for individual use. 